\title{
Low-dose ketoconazole-fluconazole combination versus fluconazole in single doses for the treatment of vaginal candidiasis
}

\author{
Jan Susilo, ${ }^{1}$ Arini Setiawati, ${ }^{2}$ Iwan Darmansjah, ${ }^{2}$ Junita Indarti, ${ }^{3}$ Fitriyadi Kusuma ${ }^{3}$ \\ ${ }^{1}$ Former Staf of Department of Parasitology, Faculty of Medicine, Universitas Indonesia, Jakarta Indonesia \\ ${ }^{2}$ Clinical Trial Center, Medical Faculty, Universitas Indonesia, Jakarta, Indonesia \\ ${ }^{3}$ Department of Obstetrics and Gynecology, Faculty of Medicine, Universitas Indonesia / Dr. Cipto Mangunkusumo General National \\ Hospital, Jakarta, Indonesia
}

\begin{abstract}
Abstrak
Latar belakang: Kandidiasis vaginal (KV) adalah salah satu penyakit jamur yang paling sering dijumpai. Candida albicans adalah jamur penyebab yang paling sering dan telah diisolasi dari lebih $80 \%$ spesimen yang diperoleh dari wanita dengan KV. Ketokonazol adalah obat jamur oral yang pertama, dosisnya untuk KV $200 \mathrm{mg} 2 x$ sehari selama 5 hari. Flukonazol, obat jamur oral yang lebih baru, diberikan untuk KV sebagai dosis tunggal $150 \mathrm{mg}$. Karena flukonazol $150 \mathrm{mg}$ cukup mahal, dosis tunggal $100 \mathrm{mg}$ ketokonazol dan $40 \mathrm{mg}$ flukonazol dalam kombinasi telah diuji untuk pengobatan KV. Hasil uji pendahuluan pada 11 wanita dengan diagnosis pasti KV, setelah 1-2 minggu pemberian obat, kultur mikologis negatif pada 8 wanita, positif pada 1 wanita, dan 2 wanita tidak kembali. Hasil yang baik ini menyebabkan penelitian ini dilakukan dengan tujuan untuk mengkonfirmasi observasi tersebut dalam uji klinik yang formal.
\end{abstract}

Metode: Sejumlah 165 pasien wanita 18 tahun ke atas, dengan diagnosis KV yang ditegakkan berdasarkan gejala klinik (rasa gatal atau rasa terbakar atau pengeluaran cairan dari vagina yang berlebihan) dan pulasan mikroskopik positif (pseudohifa dan/atau sel ragi) dirandom untuk mendapat dosis tunggal kombinasi keto-fluko $(n=85)$ atau flukonazol $(n=80)$, dan kembali pada hari ke-8.

Hasil: Tigapuluh sembilan pasien tidak mempunyai Candida pada kultur awal, sehingga tinggal 126 pasien yang dapat dievaluasi untuk efikasi. Eradikasi mikologis dalam kelompok keto-fluko 74,5\% (41 pasien dari total 55 pasien yang mempunyai kultur mikologis), sedangkan dalam kelompok flukonazol 70,2\% (40 pasien dari 57 pasien yang mempunyai kultur mikologis), dan perbedaan ini tidak bermakna. Respons klinik (kesembuhan dan perbaikan klinik) dalam kelompok keto-fluko $(n=60) 98,3 \%$, sedangkan dalam kelompok flukonazol $(n=66) 100 \%$. Kejadian tidak diinginkan ditemukan pada 5 pasien, 3 pasien pada kelompok keto-fluko (3/85 = 3,5\%) dan 2 pasien pada kelompok flukonazol (2/80 = 2,5\%).

Kesimpulan: Uji klinik ini menunjukkan bahwa efikasi dan keamanan kombinasi ketokonazol $100 \mathrm{mg}$ dengan flukonazol $40 \mathrm{mg}$ tidak inferior dibandingkan dengan flukonazol $150 \mathrm{mg}$ dalam dosis tunggal untuk pengobatan kandidiasis vaginal. (Med J Indones 2011; 20:205-11)

\begin{abstract}
Background: Vaginal candidiasis (VC) is one of the most common fungal diseases. Candida albicans is the most common causative fungus and has been isolated from more than $80 \%$ of specimens obtained from women with VC. Ketoconazole is the first orally active antifungal, the dosage for VC is $200 \mathrm{mg}$ twice daily for 5 days. Fluconazole is the newer oral antifungal, its dosage for VC is a single oral dose of $150 \mathrm{mg}$. Since fluconazole $150 \mathrm{mg}$ is considerably expensive, a single dose of $100 \mathrm{mg}$ ketoconazole and $40 \mathrm{mg}$ fluconazole in combination has been tested for the treatment of VC. The results showed that from 11 women with confirmed VC, 1-2 weeks after drug administration, the mycological culture was negative in 8 women, positive in 1 woman, and 2 woman lost to follow-up. This promising result led to the present study with the objective to confirm the efficacy and safety of the above combination in a formal clinical trial.
\end{abstract}

Methods: A total of 165 female patients, aged 18 years or older, with the diagnosis of VC from clinical symptoms (pruritus or burning or excessive discharge) and positive microscopic smear (pseudohyphae and/or yeast cells) were randomized to receive a single dose of either keto-fluco combination $(n=85)$ or fluconazole $(n=80)$, and returned for follow-up visit on day 8.

Results: Among these patients, 39 patients had negative baseline culture, leaving 126 patients eligible for efficacy evaluation. The mycological eradication in the keto-fluco group was $74.5 \%$ (41 patients from a total of 55 patients with available mycological culture), while that in the fluconazole group was $70.2 \%$ (40 patients from 57 patients with available culture) and this difference was not significant. The clinical favorable response (clinical cure and clinical improvement) in the keto-fluco arm $(n=60)$ was $98.3 \%$, while that in the fluconazole group $(n=66)$ was $100 \%$. Adverse events were found in 5 patients, 3 patients in the keto-fluco group $(3 / 85=3.5 \%$ ) and 2 patients in the fluconazole group $(2 / 80=2.5 \%)$.

Conclusion: The present study showed that the efficacy and safety of ketoconazole $100 \mathrm{mg}$ and fluconazole $40 \mathrm{mg}$ combination was not inferior compared to fluconazole $150 \mathrm{mg}$ in single doses for the treatment of vaginal candidiasis. (Med J Indones 2011; 20:205-11)

Key words: fluconazole, low-dose ketoconazole-fluconazole combination, single dose, vaginal candidiasis 
Vaginal candidiasis (VC) is one of the most common fungal diseases. It is estimated that three quarters of all adult women worldwide suffer from this condition at some time during their lives, and in many the disease is recurrent. Candida albicans is the most common causative fungus and has been isolated from more than $80 \%$ of specimens obtained from women with VC. The prime symptom of this infection is itch, worse at night, and exacerbated by warm climate. Burning vulval discomfort, dysuria, dyspareunia, and vaginal discharge are common accompanying complaints. The absence of a fishy odor distinguishes the condition from bacterial vaginosis. The discharge is usually thick and cheesy. Diagnosis is made from the presence of filamentous forms and spores of Candida seen under microscope. Bacterial vaginosis and trichomoniasis are easily differentiated from candidiasis by microscopy. ${ }^{1}$

Ketoconazole has been the first orally active antifungal, the dosage for VC is $200 \mathrm{mg}$ twice daily for 5 days. It is a potent inhibitor of some cytochrome P450 enzymes, particularly CYP3A4, which mediate the metabolism of many drugs and the synthesis and/or metabolism of endogeneous steroids such as cortisol, estradiol and testosterone. It may also increase the level of hepatic enzymes during therapy and hepatotoxicity has been estimated to occur in $0.1-1.0 \%$ of treated patients. ${ }^{2}$ Fluconazole is a newer oral antifungal. It is more potent than ketoconazole against Candida albicans, has less potential to interact with other drugs or steroids, and has little effect on the liver. ${ }^{3}$ It is administered as a single oral dose of $150 \mathrm{mg}$, which produces concentrations in vaginal tissue and secretion within the MIC range for Candida albicans for more than 48 hours. ${ }^{4}$

Since fluconazole $150 \mathrm{mg}$ is considerably expensive, low doses of fluconazole in combination with low doses of ketoconazole are being tested against Candida albicans in an attempt to substitute the single high dose of fluconazole with a single dose of the combination, as a therapy of VC with lower cost. Besides cost consideration, combination of 2 different drugs may retard the development of resistance. Although ketoconazole and fluconazole belong to the same azole antimycotics and therefore may have the same major antimycotic action, these drugs are from different subclasses and hence may have different additional unknown antimycotic actions. These may contribute to the total antimycotic action, and in combination may be expected to delay the emergence of resistant fungi.

An in vitro study by the principal investigator (JS) with an isolate of Candida albicans from a patient with pulmonary disease showed that the MIC of ketoconazole is $1 \mathrm{mcg} /$ $\mathrm{mL}$ and that of fluconazole is $0.2 \mathrm{mcg} / \mathrm{mL}$. In combination, the MIC of ketoconazole is $1 \mathrm{mcg} / \mathrm{mL}$ and that of fluconazole is $0.1 \mathrm{mcg} / \mathrm{mL}$ (unpublished observations). A single dose of $200 \mathrm{mg}$ ketoconazole produces mean peak serum concentration of approximately $3.5 \mathrm{mcg} /$ $\mathrm{mL},{ }^{5}$ while a single dose of $150 \mathrm{mg}$ fluconazole produces a mean peak serum concentration of $2.6 \mathrm{mcg} / \mathrm{mL}$ (range $1.6-3.6 \mathrm{mcg} / \mathrm{mL}$ ). ${ }^{5}$ Therefore, a combination of $100 \mathrm{mg}$ ketoconazole and $40 \mathrm{mg}$ of fluconazole produces serum concentrations of ketoconazole and fluconazole which are higher than the MIC of ketoconazole and much higher than that of fluconazole.

A preliminary study using a mixture of $100 \mathrm{mg}$ ketoconazole and $40 \mathrm{mg}$ fluconazole for the treatment of vaginal candidiasis has been carried out. Patients were women who visited the principal investigator (JS)'s private clinic with vaginal discharge as their chief complaint. As part of his daily practice, the investigator took vaginal secretion for directmicroscopic examination and vaginal swab for mycological culture. The diagnosis of VC was confirmed in 11 women and the low-dose combination was administered as a single oral dose. One to 2 weeks after drug administration, the mycological culture was negative in 8 women, positive in 1 woman, while 2 women did not return for follow-up (unpublished observations). The one failure in mycological cure may, based on the investigator's experience, be due to her long fingernails that may become the yeast colonization site, which eventually cause reinfection. ${ }^{6}$

Since the low-dose combination is meant to substitute the single high dose of fluconazole in the treatment of VC, the efficacy and safety of both preparations should be compared in a formal clinical trial with appropriate design and conducted according to GCP (Good Clinical Practice).

The objectives of the present study were to compare the efficacy and safety of $100 \mathrm{mg}$ ketoconazole and 40 mg fluconazole combination with $150 \mathrm{mg}$ fluconazole in single doses for the treatment of proven VC. The efficacy of the combination was expected to be not inferior compared to that of $150 \mathrm{mg}$ fluconazole for the treatment of VC.

\section{METHODS}

\section{Patients}

Female outpatients, aged 18 years or older, with proven VC were recruited into the study. The clinical diagnosis was confirmed initially by a positive microscopic smear (pseudohyphae and/or yeast cells), and subsequently by a positive pretreatment culture after patient's inclusion. Only symptomatic patients with a minimum of pruritus or burning or excessive discharge, and a positive smear and culture, were eligible for entry into this study. 
Excluded from the study were pregnant or lactating women, women with trichomoniasis or bacterial vaginosis (syphilis, gonorrhea, chlamydial infection, Gardnerella vaginalis infection) or nonspecific vaginitis, patients with clinically significant renal or hepatic dysfunction, patients with uncontrolled underlying disease such as diabetes mellitus, and patients with known HIV seropositivity or with clinically diagnosed AIDS or its related complex. Also excluded were patients receiving therapy with immunosuppressants (including high doses of long-term corticosteroids), antifungal (including topical agents), rifampicin, barbiturates, carbamazepine or phenytoin, each within the previous 3 weeks. Other exclusions were concurrent therapy with $\mathrm{H}_{2}$ blockers, proton pump inhibitors, antacids, warfarin or sulfonylureas. Known hypersentivity to azole antifungal agents, history of alcoholism, drug abuse or psychosis, and patients with doubtful compliance were also excluded. These conditions were excluded by anamnesis and routine clinical examination.

The study started in June 2003 and was closed in around July 2007 although the intended sample size had not been reached (sample size estimation: see below). Because most patients with VC had mixed infection with bacterial vaginosis, the protocol was amended in June 2005 to include these patients and they also received doxycycline 2 times $100 \mathrm{mg} /$ day for 5 days.

\section{Study design and procedure}

This was a randomized, single-blind (blind investigators), parallel group study, ketoconazole-fluconazole combination versus fluconazole, performed in female outpatients with proven VC who visited the private clinic of the principal investigator (JS) and the Obgyn Clinic at Dr. Cipto Mangunkusumo General National Hospital, Jakarta, Indonesia. The study protocol was approved by the Ethics Committee of the Faculty of Medicine, University of Indonesia, Jakarta, and the study was conducted in compliance with Good Clinical Practice. Informed consent was obtained from every patient before screening.

Medical history, physical and gynecological examinations were carried out for each patient before entering the study. A pregnancy test was performed only if pregnancy was suspected.

At the initial examination, a vaginal swab was obtained from each patient with a clinical diagnosis of vulvovaginal candidiasis. The patient may enter the study based on the presence of pruritus, burning, and/or excessive discharge, and a Candida positive microscopic smear, showing the presence of yeast cells or pseudohyphae on the smear. The diagnosis was subsequently confirmed by a positive culture for
Candida. The culture for Candida was partly done at the Parasitology Laboratory, Faculty of Medicine, University of Indonesia, and partly at Exacta Laboratory, the private laboratory of the principal investigator.

The investigational product, capsules containing ketoconazole $100 \mathrm{mg}$ and fluconazole $40 \mathrm{mg}$ combination, and the comparator, fluconazole $150 \mathrm{mg}$ capsules (Diflucan ${ }^{\circledR}$ 150, PT Pfizer Indonesia) were provided by PT Kalbe Farma, Jakarta. Treatment allocation was according to block-randomization using random permuted blocks of size 8 .

Eligible patients received either one capsule of the drug combination or one capsule of fluconazole as a single drug to be swallowed with the evening meal of the first day. In an attempt to prevent reinfection from the partner, each patient also received one tube of ketoconazole cream $\left(\mathrm{Mycoral}^{\circledR}\right.$ ) to be used by the patient's partner. Patients were advised to refrain from sexual intercourse until the follow-up visit (day 8) or if sexual intercourse was unavoidable, the partners were asked to use a condom or the ketoconazole cream prior to the intercourse. Use of any other antimycotic, either oral (including herbal medicine) or topical (including vaginal medications or douches of potassium permanganate or betel leaves) was prohibited during the study. Patients were advised on methods of hygiene to prevent the spread of their infection. They should have their own towel and toilet equipment, cut their nails, and not using water in the public toilet.

At the follow-up visit (day 8), pelvic examinations were again performed, and vaginal smear and vaginal swab were taken.

Mycological examination was performed on vaginal swab which was inoculated on Sabouraud chloramphenicol agar, or its equivalent, for culture of Candida, examined after 48 hours of incubation at $37^{\circ} \mathrm{C}$. Vaginal smear was also examined by direct microscopy at the same time as the swabbing. These examinations were carried out at baseline (day-1) and at after-treatment (day-8) visits.

Signs and symptoms of VC, consisting of 4 signs (vulvar erythema, edema, fissures and tenderness) and 4 symptoms (vaginal discharge, vulvar itching, burning and irritation), were recorded for their presence or absence by the investigator at each visit : baseline (day 1) and followup (day 8). The presence or absence of these symptoms of VC were also recorded by the patients themselves every day on the diary card provided. Any adverse events reported were noted in the case report form.

\section{Assessments}

For inclusion in the efficacy analysis, a patient must be symptomatic and must have a Candida positive microscopic smear at the baseline visit, which were subsequently confirmed by a positive culture for Candida. 
The primary efficacy endpoint was the mycological cure, i.e. complete eradication of baseline Candida, indicated by both negative culture and microscopy from vaginal swab and vaginal smear on day-8. The secondary efficacy endpoints were the clinical cure (the disappearance of all signs and symptoms of VC on day 8 ), the total cure (the clinical cure and the mycological cure on day 8), and the rate of total disappearance of symptoms of VC from the patient diary cards.

\section{Sample size}

Sample size was estimated based on the mycological cure (the primary endpoint) by fluconazole, which was around 85\%.7 The present study was designed to show that the efficacy of ketoconazole $100 \mathrm{mg}$ and fluconazole $40 \mathrm{mg}$ combination was not inferior compared to fluconazole $150 \mathrm{mg}$. A total number of 194 patients were required when the non-inferiority margin was determined to be $15 \%$, with a statistical power of $90 \%$ and one-sided significance level of 0.05 was used.

\section{Data analyses}

Besides descriptive statistics, $\mathrm{X}^{2}$ or Fisher exact test was used to compare the response rates (mycological, clinical and total cure) in both treatment groups (keto-fluco vs fluco). Mann-Whitney test was used to compare the time to complete relief of symptoms between the 2 groups.

For safety analysis, adverse events, whether considered related or unrelated to the study drug by the investigator, were listed with their respective incidences.

\section{RESULTS}

\section{Patients}

A total of 213 patients were screened and 48 patients were either ineligible to be included in the study or loss to follow up after visit 1 , and hence were excluded from evaluation. Among the remaining 165 patients who returned for visit 2, 39 patients did not have Candida at baseline (negative baseline culture). Therefore, there were 165 patients eligible for safety evaluation, but only 126 patients were eligible for efficacy evaluation. The demographics and baseline characteristics of the safety population are presented in Table 1 . The mean age of patients in both groups were similar, around 34 years. The current VC ( $>3$ episodes in the previous year) were also similar in both groups, around $23 \%$.

\section{Efficacy}

Among the 126 patients who were eligible for efficacy, 60 patients received ketoconazole-fluconazole combination and 66 patients received fluconazole. The mycological eradication rate (from vaginal smear and vaginal swab on day 8) are presented in Table 2.

The mycological cure in the ketoconazole-fluconazole group was somewhat higher than in the fluconazole group $(74.5 \%$ versus $70.2 \%$, calculated from the number of patients with available mycological culture), but the difference was not significant. The disappearance of all or partial signs and symptoms on day 8 (clinical cure or improvement) are presented in Table 2.

The clinical cure was the same in both groups (50.0\%), also the favourable clinical response was similar in both groups (98.3\% versus 100.0\%).

The total cure (the mycological cure and the clinical cure) on day 8 are shown in Table 2.

The total cure in both groups were similar, 49.1\% in ketoconazole-fluconazole group, and $47.4 \%$ in fluconazole group.

Table 1. Demographics and baseline characteristics of the safety population

\begin{tabular}{|c|c|c|c|}
\hline & & Keto-Fluco combination & Fluconazole \\
\hline \multicolumn{2}{|l|}{ Number of patients } & 85 & 80 \\
\hline \multirow[t]{2}{*}{ Age (yr) } & Mean (SD) & $34.5(8.76)$ & 33.9 (9.79) \\
\hline & Median (range) & $35(18-54)$ & $30(19-63)$ \\
\hline \multirow[t]{2}{*}{ Weight (kg) } & Mean (SD) & $55.0(9.07)$ & $53.9(9.44)$ \\
\hline & Median (range) & $53(38-83)$ & $52(38-85)$ \\
\hline \multirow[t]{2}{*}{ History of VC } & First & $42(49.4 \%)$ & 43 (55.1\%) \\
\hline & Recurrent & $43(50.6 \%)$ & 35 (44.9\%) \\
\hline \multirow[t]{3}{*}{ Recurrent episode } & $2^{\text {nd }}$ & 14 (32.5\%) & $10(28.6 \%)$ \\
\hline & $3^{\text {rd }}$ & $9(20.9 \%)$ & $4(11.4 \%)$ \\
\hline & $>3^{\text {rd }}$ & $10(23.3 \%)$ & $8(22.9 \%)$ \\
\hline \multirow[t]{2}{*}{ Previous treatment } & Yes & $13(15.3 \%)$ & $10(12.7 \%)$ \\
\hline & No & 72 (84.7\%) & 69 (87.3\%) \\
\hline
\end{tabular}


Table 2. Mycological and clinical response on day 8

\begin{tabular}{lccc}
\hline & $\begin{array}{c}\text { Keto-Fluco } \\
\mathbf{n}(\%)\end{array}$ & $\begin{array}{c}\text { Fluconazole } \\
\mathbf{n}(\%)\end{array}$ & Keto-Fluco vs Fluconazole \\
\hline Mycology (N) & $55(100.0)$ & $57(100.0)$ & \\
$\quad$ Absent (mycological cure) & $41(74.5)$ & $40(70.2)$ & $\mathrm{X}^{2}=0.093$ (NS) \\
Present (mycological failure) & $14(25.5)$ & $17(29.8)$ & \\
Clinical response (N) & $60(100.0)$ & $66(100.0)$ & Fisher exact test \\
Favorable & $59(98.3)$ & $66(100.0)$ & $\mathrm{p}=\sim(\mathrm{NS})$ \\
- Cure (complete relief) & $30(50.0)$ & $33(50.0)$ & \\
- Improvement (partial relief) & $29(48.3)$ & $33(50.0)$ & - \\
Failure & $1(1.7)$ & $57(100.0)$ & $\mathrm{X}^{2}=0.00005$ (NS) \\
Total (Mycology and Clinical) (N) & $55(100.0)$ & $27(47.4)$ & \\
Total cure & $27(49.1)$ & $30(52.6)$ & \\
Mycological or clinical failure & $28(50.9)$ & & \\
\hline
\end{tabular}

The time to complete relief of symptoms can be seen in Table 3.

Table 3. Days to complete resolution of symptoms of VC

\begin{tabular}{llll}
\hline & Keto-Fluco & Fluco & Keto-Fluco vs Fluco \\
\hline Mean (SD) & $4.8(2.08)$ & $4.4(1.59)$ & $\mathrm{Z}=0.775(\mathrm{NS})$ \\
Median (Range) & $4(2-8)$ & $4(2-7)$ & \\
\hline
\end{tabular}

The mean time to complete relief of symptoms were also not different between the 2 groups, 4.8 days and 4.4 days.

\section{Safety}

Adverse events were found in 5 patients, 3 patients in the ketoconazole-fluconazole group (3.5\%), and 2 patients in fluconazole group (2.5\%) (see Table 4). No patient discontinued therapy due to adverse event and no serious adverse event was encountered in this study.

Table 4. Adverse events in keto-fluco and fluconazole groups

\begin{tabular}{lcccc}
\hline & \multicolumn{2}{c}{$\begin{array}{c}\text { Keto-Fluco } \\
(\mathrm{n}=85)\end{array}$} & $\begin{array}{c}\text { Fluco } \\
(\mathrm{n}=80)\end{array}$ \\
\cline { 2 - 5 } Adverse event & Total & $\begin{array}{c}\text { Considered } \\
\text { related }\end{array}$ & Total & $\begin{array}{c}\text { Considered } \\
\text { related }\end{array}$ \\
\cline { 2 - 5 } Nausea & 3 & 3 & 1 & 1 \\
Headache & 1 & 1 & 1 & - \\
Total & 4 & 4 & 2 & 1 \\
\hline
\end{tabular}

\section{DISCUSSION}

The results of the present study showed that the efficacy of ketoconazole $100 \mathrm{mg}$ and fluconazole 40 mg combination was not inferior to that of fluconazole $150 \mathrm{mg}$ in the treatment of proven VC. Since the combination of ketoconazole and fluconazole was a new combination that never existed before, we cannot make comparison of its efficacy with previous studies.
However, the history of a single oral dose of $150 \mathrm{mg}$ fluconazole for the treatment of VC was well-known.

Reyes et al. ${ }^{8}$ reviewed 14 noncomparative and 14 comparative clinical studies conducted in Europe, Asia, Africa, and Latin America from 1982 to 1992, the safety and efficacy of a single oral dose of fluconazole $150 \mathrm{mg}$ for treating VC. A total of 4,942 patients were treated, 3,729 with fluconazole, and 1,213 with comparative agents. At short-term follow-up (6 to 14 days after treatment began), the mycological eradication was 85\% (range 76-98\%) in 2,307 mycologically evaluable patients, and the favorable clinical response was $94 \%$ (range 88-100\%) in 3,729 evaluable patients. ${ }^{8}$ In one of the largest comparative study (versus itraconazole), the favorable clinical response at short-term evaluation was $94 \%$ in fluconazole group, consisting of clinical cure $71 \%$ and clinical improvement $23 \%{ }^{9}$

Troke in 1996 pooled all 16 comparative trials for the treatment of VC in the Pfizer database from 1982 to $1995 .^{10}$ A total of 1,340 women were treated with a single $150 \mathrm{mg}$ oral dose of fluconazole and 1,292 women with one of 10 competitor oral or topical agents and various dose regimens. The mean (range) shortterm (14 days) clinical and mycological response for the single dose of fluconazole were 96 (88-99)\% and 83 (76-92)\%, respectively. ${ }^{10}$

In 1995, Sobel et al. ${ }^{11}$ repeated the single dose fluconazole for VC study, compared to clotrimazole topical therapy. The mycological cure in 182 patients receiving fluconazole at short-term (14-day) evaluation was $77 \%$ (81\% in patients with $<4$ episodes of vaginitis in the prior year, and $63 \%$ in patients with recurrent VC, i.e. $\geq 4$ episodes), while the clinical response was 94\% (73\% cured, 21\% improved). The 73\% clinical cure consisted of $78 \%$ in patients with $<4$ episodes of vaginitis in the prior year and 58\% in patients with recurrent VC. ${ }^{11}$ 
According to Sobel ${ }^{12}$ in 1992, there were no published reports of resistance in Candida albicans isolates to azole therapy (either topical or systemic) in VC, despite of long-term daily low dosage or cyclical therapy with ketoconazole or monthly single oral dose therapy with fluconazole. ${ }^{12}$ Ten years later, in 2002, Sobel found that 96\% of 393 Candida albicans isolates from complicated candidal vaginitis were still highly susceptible to fluconazole (MICs $<8 \mathrm{mcg} / \mathrm{mL}$ ), and therefore susceptibility testing for these women were regarded unjustified..$^{13}$ In 2004, Sobel found no fluconazole resistance among 401 Candida albicans isolates recovered from women with recurrent vulvovaginitis, who were maintained with fluconazole therapy. ${ }^{14}$ These findings were supported by Mohanty et al. ${ }^{15}$ in 2007 who found a low prevalence of fluconazole resistance in vaginal Candida isolates $(10 \%)$ at a rural community in India, and therefore use of fluconazole may be continued for empirical therapy of uncomplicated candidal vulvovaginitis in the community.

In the present study, the mycological cure by fluconazole (70.2\%) was somewhat lower but not statistically different from that by ketoconazolefluconazole combination (74.5\%), and also from that by fluconazole in published reports (the lowest was $76 \%)^{8,10}$ This sustained efficacy of a single dose fluconazole for the treatment of VC may be due to the sustained susceptibility of Candida albicans to fluconazole, as already demonstrated by Sobel et al. ${ }^{13,14}$ and Mohanty et al. ${ }^{15}$

The clinical response was found similar for both fluconazole and ketoconazole-fluconazole combination (98-100\%), and much higher than the mycological response (70-75\%), but different from the published reports in the proportion of clinical cure and improvement. In the present study, the clinical cure was only $50 \%$ for both treatments, while in published reports it was around 70\%. ${ }^{9,11}$ This discrepancy may be due to the subjective evaluation of clinical response which is difficult to standardize.

Sobel et al. in $1995^{11}$ differentiated the mycological cure rate and clinical cure rate in recurrent VC and nonrecurrent $\mathrm{VC}$, in which the cure rates in recurrent $\mathrm{VC}$ were much lower than those in non-recurrent VC. In the present study, the number of patients with recurrent VC was too small (8 in fluconazole group and 10 in keto-fluco group) to make comparison with non-recurrent VC.

The time to complete relief of symptoms were the same for both treatment groups, with a median of 4 days and a mean of 4 to 5 days. Previous studies showed that the median time for complete symptom relief for fluconazole was 3 to 4 days. ${ }^{8,9}$
The incidence of adverse events in patients treated with fluconazole $150 \mathrm{mg}$ single dose was around $7 \%$ to $10 \%$, mostly of mild severity, and the most common were nausea and headache., ${ }^{2,8}$ Lower incidence with the same pattern of adverse events was found in the present study.

In conclusion, the present study showed that the efficacy and safety of ketoconazole $100 \mathrm{mg}$ and fluconazole 40 mg combination was not inferior compared to those of fluconazole $150 \mathrm{mg}$ in single doses for the treatment of vaginal candidiasis. Meanwhile, the efficacy of fluconazole $150 \mathrm{mg}$ single dose in the present study was somewhat lower compared to its performance in the previous studies.

\section{Acknowledgments}

We thank the study patients for their participation, the study personnel for their commitment, especially Dinah Kartanegara for performing the mycological culture, and PT Kalbe Farma for providing the test drugs and for funding the study.

\section{REFERENCES}

1. Kinghorn GR. Medical overview of vaginal candidiasis. Int J Gynecol Obstet. 1992; 37(Suppl): 3-8.

2. Kutzer, Oittner R, Leodolter S, Brammer KW. A comparison of fluconazole and ketoconazole in the oral treatment of vaginal candidiasis; report of a double-blind multicentre trial. Eur J Obstet Gynecol Reprod Biol. 1988; 29: 305-13.

3. Grant SM, Clissold SP. Fluconazole:a review of its pharmacodynamic and pharmacokinetic properties, and therapeutic potential in superficial and systemic mycoses. Drugs. 1990; 39(6): 877-916.

4. Dellenbach P. Penetration of fluconazole into vaginal tissues and secretions. In: Richardson RG, editor. Fluconazole and its role in vaginal candidiasis. London: Royal Society of Medicine Services. 1989: 19-22.

5. Physicians' Desk Reference. $54^{\text {th }}$ ed. 2000.

6. Puji KS, Kartanegara D, Susilo J. Keberadaan Candida sp. di bawah kuku pada penderita vaginitis. Seminar Parasitologi Nasional ke-VII, Kongres P4I ke-VI. Bali, 23-25 Agustus 1993.

7. Weström L, Haglund A, Svensson L. Fluconazole versus econazole in treating vaginal candidiasis. Int J Gynecol Obstet. 1992; 37 (Suppl): 29 - 31.

8. De los Reyes C, Edelman DE, De Bruin MF. Clinical experience with single-dose fluconazole in vaginal candidiasis : a review of the worldwide database. In: Sobel JD, Kinghorn GR, eds. Vaginal Candidiasis Symposium. Int J Gynecol Obstet. 1992; 37 (Suppl): 9-15.

9. Rees T, Phillips R. Multicenter comparison of one-day oral therapy with fluconazole or itraconazole in vaginal candidiasis. In: ibidem: 33-8.

10. Troke PF. Fluconazole:its properties and efficacy in vaginal candidiasis. In: Elsner P, Eichmann A, eds. Sexually transmitted diseases : advances in diagnosis and treatment. Curr Probl Dermatol. 1996; 24: 203-8.

11. Sobel JD, Brooker D, Stein GE, Thomason JL, Wermeling DP, Bradley B, Weinstein L, and the Fluconazole Vaginitis 
Study Group. Single oral dose fluconazole compared with conventional clotrimazole topical therapy of Candida vaginitis. Am J Obstet Gynecol. 1995; 172(4, part 1): 1263-8.

12. Sobel JD. Antimycotic azole resistance in vulvovaginal candidiasis. In: Sobel JD, Kinghorn GR, eds. Vaginal Candidiasis Symposium. Int J Gynecol Obstet. 1992; 37(Suppl) : 39-43.

13. Sobel JD, Zervos M, Reed BD, Hooton T, Soper D, Nyirjesy $\mathrm{P}$, et al. Fluconazole susceptibility of vaginal isolates obtained from women with complicated Candida vaginitis : clinical implications. Antimicrob Agents Chemother. 2003; 47: 34-8.

14. Sobel JD, Wiesenfeld HC, Martens M, Danna P, Hooton TM, Rompalo A, et al. Maintenance fluconazole therapy for recurrent vulvovaginal candidiasis. N Engl J Med. 2004; 351: 876-83.

15. Mohanty S, Xess J, Hasan F, Kapil A, Mittal S, Tolosa JE. Prevalence and susceptibility to fluconazole of Candida species causing vulvovaginitis. Indian J Med Res. 2007; 126: 216-9. 